\title{
Age of onset
}

INSERM

\section{Source}

INSERM. (1999). Orphanet: an online rare disease and orphan drug data base. Age of onset. ORPHA:CO23

Age of onset of clinical manifestations related to a clinical entity. 